\title{
The Music Manuscript Period; A Background Essay and Bibliographical Guide
}

\begin{abstract}
The characteristics of music, notation, principal manuscripts, and contemporary literature on music are described briefly for each of five chronological periods; namely: antiquity, early Christian through the sixth century; seventh through the tenth centuries; eleventh through the thirteenth centuries; and the fourteenth and fifteenth centuries. The resulting outline is intended as an aid for the "non-musicological music, humanities, or reference librarian who needs to have an understanding of the nature of music materials in the pre-printing era, whether or not he is actually charged with handling them."
\end{abstract}

\begin{abstract}
A NOTHER ASPECT of these plays which has been generally unexplored is their melodies ... . since the plays of the Church were actually sung, our knowledge of them cannot be complete until such of their music as exists has been published, elucidated and heard. I am not a specialist in the theory of plain-song or in musical palaeography.... The adequate editing and exposition of the music associated with the dramatic texts might well require a separate treatise equal to the present one in extent. Such a study would undoubtedly aid in the interpretation of certain texts, would assist a demonstration of relationships, and would probably disclose unsuspected traditional aims or originalities throughout the body of plays.
\end{abstract}

These remarks by Karl Young, in the preface to his monumental Drama of the Medieval Church (Oxford, 1933), point

Dr. Marco is Chairman of the Department of Library Science, Kent State University, Ohio. up the interdisciplinary function which musicology was even then assuming. Today it is not unusual for students of religion, drama, poetry, linguistics, and numerous other fields to find themselves -when their researches lead into medieval times-involved with musical documents. One is not surprised to find the facsimile of a fourteenth-century music manuscript used as frontispiece to a volume of Chambers' Medieval Stage nor to see Speculum review books by musical specialists in the middle ages. A recent list of sources dealing with Tudor poetry and music permits easy observation of the considerable number of poetic remnants which contain "tunes," "bass-part of a set of part-songs," "lute tablatures," "plain-song Magnificats," and other "notational matter." 1

Thus the reference or humanities librarian may well be confronted with

\footnotetext{
1 John Stevens, Music and Poetry in the Early Tudor Court (Lincoln: University of Nebraska Press, 1961), pp.461-68.
} 
manuscripts that are musical at least in part, or with questions about them, though he himself is likely to have no deep knowledge about them; indeed such knowledge would hardly be a normal part of his background:

The librarian of a research library should be a musicologist with some training in library techniques whereas the librarian of a school or college library is first of all a librarian with a strong musical background. ... The training required for the librarian of the public library's music department is essentially the same as that of the school librarian. $^{2}$

The present essay is for this nonmusicological music, humanities, or reference librarian who needs to have an understanding of the nature of music materials in the pre-printing era, whether or not he is actually charged with handling them. To profit from this presentation, the reader must expect to consult a fair number of the books and articles cited in footnotes, as the text itself touches only quickly on highlights and ignores numerous complexities entirely.

These venerable documents pose problems which are by nature quite formidable, since the music involved is generally unfamiliar to nonspecialists and its bibliographical features are highly esoteric. Yet it is hoped that this little survey will offer some guides and points of departure, as well as a collection of references which may later prove useful. The reader who follows the thread attentively will discover that the labyrinth is not hopeless, and at the exit he might be equipped to classify, date (to the century), and to some extent interpret typical survivors of the music manuscript period. Certainly he will be able to offer guidance to patrons in need of basic or specialized readings.

It has seemed preferable to make repeated citations to a limited number of particularly valuable works with strong

'Lester Asheim, The Humanities and the Library (Chicago: ALA, 1957), pp.173-74, 177. bibliographies-such as those of Reeserather than to compound the number of footnote references unnecessarily. Both of the great contemporary musical encyclopedias, Grove's Dictionary of Music and Musicians and Musik in Geschichte und Gegenwart, are worthy of consultation at nearly any point, but in the interest of space conservation specific references have not as a rule been made to them.

The music manuscript period begins in Hellenic Greece and ends with the application of printing techniques to the setting down of music in the late fifteenth century. Musical scores were still hand produced, at least in part, after the printing of books had become widespread. The Psalterium printed by Fust and Schöffer at Mainz in 1457 is the earliest extant printed book containing music, but the music seems to have been manually inscribed. Later practice involved printing either the notes or the staff lines and completing the score by hand, this procedure arising from an inability to achieve accurate imposition in printing notes on staves. Not until the mid-1470's are there examples of printed notes and lines. ${ }^{3}$

In the survey which follows, these subdivisions are utilized: antiquity, early Christian through sixth century, seventh through tenth centuries, eleventh through thirteenth centuries, and fourteenth

\footnotetext{
${ }^{3}$ For concise information about early music printing, see A. Hyatt King, Four Hundred Years of Music Printing (London: British Museum, 1964) Kathi Meyer and Eva Judd O'Meara, "The Printing of Music," The Dolphin. II (1935), 171-207; Gustave Reese, Music in the Renaissance (New York: Norton, 1954), pp.154-56 (hereinafter cited as Reese, Renaissance); Willi Apel, Harvard Dictionary of Music (Cambridge: Harvard University Press, 1951). pp.601-603; or Hubert Foss, "Printing," Grove's Dictionary of Music and Musicians (5th ed, : London: Macmillan, 1954), VI, 928-34. For facsimiles of early printing see Georg Kinsky, A History of Music in Pictures (London and Toronto: Dent; New York: Dutton, 1930); and A. Beverly Barksdale, The Printed Note (Toledo, Ohio: Toledo Museum of Art, 1957). A guide to other facsimiles is provided in Guy A. Marco, The Earliest Music Printers of Continental Europe (Charlottesville: Bibliographical Society of the University of Virginia, 1962). A recent list for further reading is A. D. Walker, "Music Printing and Publishing: a Bibliography," Library Association Record, I.XV (May 1963), 192-95.
} 
through fifteenth centuries. The discussion of each of these periods will be further divided into four sections: characteristics of the music, notation, principal manuscripts, and contemporary literature on music.

\section{ANTIQUTTY}

With the possible exception of one apparently indecipherable Babylonian tablet of $c a .800$ в.c. ${ }^{4}$ no examples of pre-Greek music have survived. Fewer than twenty fragments of Greek music are extant; two on marble, one on a stone slab, and the remainder on papyrus. $^{5}$

Characteristics of the Music. The principal function of music in Greece was that of adjunct to the drama and the dance. While the surviving examples are monodic (or monophonic: consisting of a single unaccompanied melody) further parts were probably improvised. The theoretical basis of Greek music is highly complex and hardly relative to this discussion. ${ }^{6}$ It may be mentioned that music to the Greeks had a moral, ethical significance which is not yet entirely explained. ${ }^{7}$

Notation. Musical paleography or handwriting, usually termed notation, assumed numerous forms before devel-

\footnotetext{
A photograph of the tablet, in conjunction with the most recent analysis of its possible musical content, appears in Curt Sachs, "The Mystery of the Babylonian Notation," Papers of the International Congress of Musicology, 1939 (New York; American Musicological Society, 1944), 161-67; als $\delta^{5}$ printed in Musical Quarterly, XXVII January, 1941), 62-69. For a recent analysis of music in this period see Henry G. Farmer, "Music in Ancient Mesopotamia," New Oxford History of Music, Vol. I: Ancient and Oriental Music (London: Oxford University Press, 1957).

"Gustave Reese, Music in the Middle Ages (New York: Norton, 1940), pp.48-49, offers brief descriptions of all of them, and provides a guide to transcriptions and facsimiles. This book by Reese will hereinafter be cited as Reese, Middle Ages.

"For a notable summation of Greek theory, see Ceeil Torr, "Greek Music," Oxford History of Music, Introductory Volume (London: Oxford University Press, 1929), pp.1-22. More detail in Reese, Middle Ages, pp.11-51. A good recent survey is Isobel Henderson, "Ancient Greek Music," New Oxford History of Music, I.

7 See Louis Harap, "Some Hellenic Ideas on Music and Character," Musical Quarterly, XXIV (April 1938), 153-68.
}

oping into our familiar system of notes and staves. The Greeks utilized what is known as letter notation, through which each pitch can be represented by a letter from one or more alphabets. Letter notation does not require a staff and is a simple, satisfactory way of writing down monophonic music if the rhythmic patterns are known to the performer or communicated to him by means of supplementary symbols; one Greek fragment includes such symbols. Two sets of letters were in use: one set for vocal music and the other for instrumental music. $^{8}$

Principal Manuscripts. Three items among the small number of survivals are of particular interest because of their age, length, and state of preservation. All are stone inscriptions discovered in the late nineteenth century. The first Delphic Hymn to Apollo is our most extensive piece of Greek music; it dates from ca. 138 в.с. The second Delphic Hymn to Apollo, also of considerable length, is about ten years younger. The Song or Epitaph of Seikilos is of uncertain date: between the years 200 B.C. and 100 A.D. ${ }^{9}$

Contemporary Literature on Music. More can be learned of Greek music from the eighteen extant treatises about it than from the few fragments of actual music preserved. Since Reese provided a commentary on these writings as well as a guide to texts and translations, it seems sufficient here only to mention the most important authors. These may be divided into three groups: those following the theories of Pythagoras (sixth century в.с.), those pursuing the somewhat conflicting views of Aristoxenos (born $c a .354$ в.C.), and those not partic-

\footnotetext{
${ }^{8}$ Both groups are shown, with modern equivalents, in Reese, Middle Ages, pp.26-27.

Transeriptions, not mentioned in Reese, Middle Ages, of the first Hymn and of the Seikilos appear in Archibald Davison and Willi Apel, Historical Anthology of Music (Cambridge: Harvard University Press, 1946), I, 9-10. This two-volume compilation is a highly valuable sources of musical examples from preclassical times. Variant transcriptions are given in Henderson, op. cit., pp.364-73.
} 
ularly associated with either of these theorists. ${ }^{10}$ The Pythagoreans were Euclid, Nicomachos, Ptolemy of Alexandria, and Porphyry; the Aristoxenians were Aristoxenos himself, Kleonides, and Bakcheios; the independents were Plato, Aristotle, Quintilianos, and Alypios.

\section{Early Christian Through Sixth Century}

This is truly a dark age for the study of western music manuscripts, for there are no surviving examples. From numerous contemporary allusions and treatises, and from later copies of pre-700 music, it has been possible to derive considerable knowledge about these lost documents. The music of these centuries is largely religious in nature, and it may appear strange that the monasteries did not preserve copies of it. Two reasons may be advanced for their failure to do so: the prevalence of oral tradition and the subsequent Gregorian reform. Both factors will receive further attention shortly.

Characteristics of the Music. So little is known about the secular music of this period that it is necessary to confine the discussion to liturgical music. Most of this sacred music falls into one of two categories: music written for the Mass (texts in the Roman Missal; music in the Gradual), and music written for the Daily Hours (texts in the Breviary; music in the Antiphonary). The character and, in some cases, the actual melodies $^{11}$ of pre-700 liturgical music have been preserved by the Roman Catholic

\footnotetext{
10 The essence of Pythagorean harmonics (and Pythagorean philosophy generally) has long eluded satisfactory analysis. The first exposition of the roots of esoteric Pythagoreanism is Hans Kayser, Lehrbuch der Harmonik (Zürich: Occident Verlag, 1950). Kayser's research derived largely from study of a rare volume by Albert Thimus: Die harmonikale Symbolik des Altertums (Köln: Dumont-Schawberg, 1868-76). The less obscure Aristoxenian tradition is well expounded by Henry S. Macran, The Harmonics of Aristoxenos (Oxford: Clarendon Press, 1902).

11 Listed speculatively in Amédée Gastoué, L'Art Grégorien (Paris: F. Alcan, 1911), pp.121 f.
}

Church, which still considers the socalled Gregorian chant to be the ideal music for divine services. These chants are monophonic, rhythmically free, and sung by cantor and unison choir. The melodies are intended solely as ornamentations of the texts: they are restricted in range, sparing in use of wide intervals, and free from dissonance or sharp contrasts. Authentic performance does not admit instrumental accompaniment. ${ }^{12}$

Pope Gregory I (590-604) appears to have instigated a reform and codification of the chant repertoire, which resulted in a curtailed but collated body of melodies. It seems reasonable to suppose that any manuscripts bearing superseded versions of a chant would not have merited preservation, and indeed the corpus of extant chant examples dates from the seventh century on.

About three thousand chant melodies remain in the present day repertoire. ${ }^{13}$

Notation. Apparently not much need for a precise notation was felt during this period. In its stead there was a strong oral tradition; chant melodies were transmitted from master to pupil and from monastery to monastery with remarkably few corruptions; it was considered sacrilegious to alter a sacred melody. Nevertheless there were inevitable local variants, and doubtless it was a principal aim of the Gregorian reform to purify them.

There is evidence that a certain system of signs, known as ekphonetic notation, had its beginnings in Byzantium during this period. Originally these

12 There is a vast literature on the chant. Harvard Dictionary, pp.304-10, offers a concise introduction and brief bibliography; Reese, Middle Ages, pp.57197, is a more detailed study, with comprehensive bibliography, pp.431-45. The biggest and finest modern compendium is Willi Apel, Gregorian Chant (Bloomington: University of Indiana Press, 1957). Higini Anglès has two useful chapters in New Oxford History of Music, II.

13 The official versions of these melodies appear in the Liber Usualis, ed. by the Benedictines of Solesmes (Boston: MeLaughlin \& Reilly, 1950). 
signs were but accents indicating a rise or fall in pitch; later they came to represent stereotyped melodic formulas. The first extant manuscript containing these signs dates from the ninth century.

Contemporary Literature on Music. The patristic writings are a source of much information regarding attitudes toward music and the function it had in early church services. ${ }^{14}$

Three men served to extend the tradition of Greek theory: Boethius (d. 524), ${ }^{15}$ Cassiodorus (479-515), ${ }^{16}$ and Isidore of Seville (565-636). ${ }^{17}$ Boethius continued the Pythagorean school and Cassiodorus that of Aristoxenos. Their writings, with those of Isidore, formed the basis of academic music study until the ninth century.

\section{Seventh Through Tenth Centuries}

Now the music manuscript period begins to flourish. There is an abundance of examples, and improved notation renders them more or less readable.

Characteristics of the Music. Gregory's codification of the plainchant became the norm for all western churches. This standardized body of melodies was not long untouched, however, for in the

14 The standard source for this material is Jacque Paul Migne, Patrologiae Cursus Completus.. (Paris, 1857-66), but it is conveniently summarized in Théodore Gérold, Les Pères de l'Eglise et la Musique (Paris: F. Alean, 1931). For guidance through Migne's 161 volumes there is a table of contents in the Catalogue of the Library of the Peabody Institute (Baltimore: Isaac Friedenwald, 1883), IV, 2908-28; and an Index Musicae to the Latin series in Vol. CCXXI, col. 625 ff. Reese, Middle Ages, 61-67, is a brief survey of patristic writings in the area.

${ }^{15}$ De Institutione Musica ... modern ed. by Gottfried Friedlein (Leipzig: B. G. Teubner, 1867). German translation: Oskar Paul, Boethius; Fün Bücher über die Musile (Leipzig: E. C. Leuckart, 1872).

16 Treatise on music reprinted in Martin Gerbert, Scriptores Ecclesiastici de Musica ... (facsimile reprint, Milan: Bollettino Bibliografico Musicale, 1931 ; first published, 1784), I, 14-19; and in Roger A. Mynors, Cassiodori Senatoris Institutiones . . . (Oxford: Clarendon Press, 1937). Partial English translation in Oliver Strunk, Source Readings in Music History (New York: Norton, 1950).

${ }^{17} \mathrm{De}$ Ecclesiastis Officiis, Migne Latin series LXXXIII, 743 f. Etymologies, III, chapter 14-22, Migne Latin series, LXXXII; modern edition by Wallace M. Lindsay, Isidori Hispalensis Episcopi Etymologiarum . . (Oxford: Clarendon Press, 1911). eighth or ninth century it was enriched by the development of tropes. These were interpolations made in the authorized texts, ranging in extent from a few amplifying words to lengthy, sentences and even entire poems. The new text was either fitted to a pre-existing musical pattern which had previously been sung on a single syllable-a so-called melismatic pattern-or sung to a new melody. Tropes which took the form of dialogues were forerunners of the liturgical drama. ${ }^{18}$

A second innovation of this period was the rise of the secular song, but there is a dearth of manuscripts in readable notation before the eleventh century.

The most important development of these four centuries was that of polyphony: the sounding and writing of two or more simultaneous melodies, in contrast to the single line monophony found earlier. ${ }^{19}$ In addition to the artistic significance of this new kind of music, we can observe a considerable impact which it had upon manuscript production and notation. The increased complexity resulting from extra voices rendered less satisfactory the practice of retaining compositions in the memory and was a reason for the larger number of manuscripts; and further, the necessity for two singers or groups of singers

18 The history of the trope is sketched in Reese, Middle Ages, pp.185-97, and in Jacques Handschin, "Trope, Sequence and Conductus," New Oxford History of Music, II. There are four examples in the Davison and Apel, op. cit. (numbers 15b, 16, 27b and 37 of Vol I).

12 The physical, physiological, psychological, and artistic factors which led to polyphony have been studied by many scholars. Some of the noteworthy contributions are: Armand Machabey, Histoire et Evolution des Formules Musicales ... (Paris: Payot, 1928 ) ; Joseph Yasser, "Medieval Quartal Harmony," Musical Quarterly, XXIII, XXIV (1937-38); Amédée Gastoué, "Moyen Age II (La Musique occidentale)," Encyclopédie de la Musique . . . ed., A. Lavignae (Paris: C. Delagrave, 1913-31), I, I, 556 ff; Anselm Hughes, "The Origins of Harmony," Musical Quarterly, XXIV (1938): Marius Schneider, Geschichte der Mehrstimmigkeit (Berlin: J. Bard, 1934-35). A somewhat onesided summary of these and other views is given by Hughes in New Oxford History of Music. II. Further bibliography in Reese, Middle Ages, pp.451-52. 
to perform different melodies simultaneously militated against improvised performance, for objectionable dissonances might be the result.

Notation. It was inevitable that notation of a sort should develop to keep pace with the changes taking place in composition; the interesting point is the direction taken by those who sought to write down music. The choice lay between the adaptation of one of the two radically different systems already known, and the invention of something completely new. The existing methods were the letter notation (originating with the Greeks; promulgated by Boethius) and the vague ekphonetic symbols. While letter notation is found in the most valuable musical document of the period, the "Musica Enchiriadis," this fairly accurate and unequivocal scheme was not generally adopted. Instead there was developed, perhaps from the ekphonetic symbols ${ }^{20}$ or Hebrew cantillation signs, ${ }^{21}$ or possibly from the Greek and Latin grammatical accent signs, a system of neumes which seemed to satisfy the practical musician, if not the theorists, for several centuries. The neumes were stylized versions of the acute, grave, circumflex and (artificial) anticircumflex accents, and indicated respectively (as the accents did) a rise in pitch, a drop, a rise and drop, a drop and rise. These signs ${ }^{22}$ were placed over the points in the text where pitch change was desired. Used in combination as well as singly, they were capable of indicating fairly complex melodic patterns and, as the system was elaborated, a number of subtleties in performance. The great

\footnotetext{
${ }^{20}$ See Jean Baptiste Thibaut, Origine Byzantine de la Notation Neumatique . . (Paris: A. Picard, 1907).

21 Amédée Gastoué, Cours Théorique et Pratique de Plainchant . . (Paris: Scola Cantorum, 1904), p.15. On the relationships among all these signs see Eric Werner, The Sacred Bridge (New York: Columbia University Press, 1959).

$n$ Illustrated, with modern equivalents, in Harvard Dictionary, p.487.
}

flaw in neumatic notation was felt only later: it was that the size of the interval was not specified with the direction. An acute, for instance, signified a rise in pitch but did not designate how much of a rise. To musicians who knew the repertoire and its idiom this fault was perhaps not serious, but it prevented the learning or singing of an unfamiliar melody "at sight."

Although the earliest extant manuscript containing neumes dates from the eighth century, ${ }^{23}$

... The history of Gregorian Chant would seem to support the assumption that neumes existed as early as the sixth century. For it is difficult to conceive how the complex task of codifying plainsong melodies could have been undertaken during the time of Gregory without the aid of some system of notation. ${ }^{24}$

In any case there is a large number of manuscripts dating from the ninth century on. ${ }^{25}$

Principal Manuscripts. The outstanding musical work of the period is the ninth-century manual "Musica Enchiriadis," the precise date and authorship of which remain in dispute. ${ }^{26}$ This trea-

23 Thtroit Ad Te Levavi, Brussels Codex 10127. 10144. Facsimile in Gregorio Suñol, Introduction d la Paléographie Musicale Grégorienne (Paris: Société de St. Jean L'Evangeliste, 1935), p.33.

24 Reese, Middle Ages, p.133. In fact the sixthcentury palimpsest, Codex 912 of St. Gall, bears traces of neumelike symbols. See Suñol, op. cit., p. 480 .

${ }^{25}$ An extensive collection of facsimiles with commentaries has been compiled by the Benedictines of Solesmes, under the title Paléographie Musicale (Tournai: Desclée, 1889-) in 17 volumes. Contents of the set are given in Reese, Middle Ages, p.441, and Harvard Dictionary, p.238.

${ }^{26}$ Note the title of A. H. Fox-Strangways' informative article about it: "A Tenth-Century Manual," Music and Letters, XIII (1932), 183-93. The treatise is reprinted by Gerbert, op. cit., I, 152-212, who attributes it to Hucbald. Locations of the numerous manuscript versions are given in Robert Eitner, Biographisch-bibliographisches Quellen-Lexikon der Musiker und Musikgelehrten ... (Leipzig: Breitkopf und Härtel, 1900-1904), V, 218-19. Although much in need of revision, Eitner remains the best guide to library locations of music manuscripts; it is however being replaced by the Répertoire International des Sonrces Musicales (1960-), a series described in a review article by Daniel Heartz, Journal of the American Musicological Society, XIV-2 (Summex 1961), 268-78 
tise is a primer of practice for early polyphony, with musical examples in letter notation. ${ }^{27}$

Contemporary Literature on Music. Two names predominate: Hucbald and Odo. Hucbald, a monk of St. Amand (ca. 840-930), is perhaps better known for things he did not write than for those he did: he was formerly thought to have been author of the "Musica Enchiriadis," and Gerbert gives him credit for the "Alia Musica" as well (see below). He is actually the author of "De Harmonica Institutione," a summary of earlier thought. ${ }^{28}$ Odo, head of the abbey of Cluny (d. 942), is responsible for a number of important writings on music, chief of which is the "Dialogus." 29

A composite work of the tenth century is "Alia Musica," of great value for the study of medieval theory. ${ }^{30}$

\section{Eleventh Through Thirteenth Centuries}

In this period the manuscripts begin to look like music as moderns think of it, for the staff makes its appearance to revolutionize notation. The number of manuscripts containing music reaches high into the thousands.

Characteristics of the Music. This is the earliest period for which we are able to recreate secular music. The most important body of material comes from the two groups of French minstrels: the troubadours (southern France, elevenththirteenth centuries; 2,600 poems and 264 melodies extant) and the trouvères (northern France, twelfth-thirteenth

\footnotetext{
${ }^{2 t}$ Davison and Apel, op. cit., ex. 25b, is a transcription of two examples.

${ }^{28}$ Printed in Gerbert, op. cit., I, 103-25. See also Rembert Weakland, "Hucbald as Musician and Theorist," Musical Quarterly, XXXXII (January 1956), 66-84.

20 Text in Gerbert, op. cit., I, 251-64; English translation in Strunk, op. cit., pp.103-16.

so Text in Gerbert, op. cit., I, 125-52. German translation: Wilhelm Mühlmann, Die Alia Musica (Leipzig: O. Brandstetler, 1914).
}

centuries; 4,000 poems with 1,400 melodies). Though monophonic, this music generally differs from plainchant in several respects: (1) it has a metrical basis and is more strongly rhythmic, (2) its melodies have a wider range and depart from the strict modality of the chant, (3) it was doubtless performed with improvised instrumental accompaniment (not in the manuscripts), and (4) with the exception of the famous Goliard Latin songs, the texts are usually in the vernacular. The German counterpart of the troubadour was the Minnesinger of the twelfth-fourteenth centuries. ${ }^{31}$

Two great schools of sacred composition highlight these centuries with their achievements in organum. "Organum" is the name given to a polyphonic composition in which the principal melody (the tenor) is a liturgical chant. The first of the schools was that of St. Martial (Limoges, early twelfth century). Its specialty was organum duplum, in which each tone of a plainchant melody was greatly extended and accompanied in a second voice by a melodic passage. The school of Notre Dame (Paris, late twelfth century) brought forth two excellent composers, among the first important composers we know by name: Leonin and Perotin. The latter added a third and fourth voice to the chant tenor (organum triplum and quadruplum), and devised a method of regulating and notating rhythmic values. Frequently their

\footnotetext{
s1 Details on these minstrels and their music may be found in Reese, Middle Ages, chapters 7 and 8 ; Pierre Aubry, Trouvères et Troubadours (Paris: F. Alcan, 1909); F. Gennrich, Rondeaux, Virelais und Balladen (Dresden: Gesellschaft für Romanische Literatur, 1921-1927) ; H. J. Moser, Geschichte der Deutschen Musik (Stuttgart und Berlin: J. G. Cotta, 1928-30). An excellent survey, with numerous transcriptions, is J. A. Westrup's "Medieval Song," New Oxford History of Music, II. It may be noted that the theories of Gennrich have been the subject of considerable controversy; for the most recent reevaluation see Willi Apel, "Rondeaux, Virelais and Ballades in French 12th-Century Song," Journal of the American Musicological Society, VII-2 (Summer 1954), 121-130.
} 
voice parts clash in sharp dissonances. ${ }^{32}$

Notation. The manuscripts show several fruitless attempts to solidify the equivocal neumatic notation or to provide a substitute for it. ${ }^{33}$ But the one significant forward step was the development of the staff. Staff notation was an outgrowth of an earlier attempt to make definite the intervals represented by the neumes, in which dots were placed in the manuscripts above the text, separated vertically from one another by relatively large or small distances, in accordance with the size of the interval. As a guide to writing the copyist scratched a line across the page horizontally, with a dry pen, and this line was soon taken to represent a degree of the scale. The line came to be inked in; and presently another line, representing a higher scale degree, was added above it, and the neumes were grouped on and between the two lines. Guido of Arezzo is the person most closely associated with the introduction of staff lines; he recommends three or four lines. The four line staff was adopted for liturgical music and remains today the vehicle for plainsong notation. ${ }^{34}$

When at the end of the twelfth century the neumes began to assume more definite, square shapes, they began to look like the notes and ligatures of mod-

\footnotetext{
32 Reese, Middle Ages, has an excellent chapter (11) on organum, as does New Oxford History of Music, II. See, for details, William G. Waite, The Rhythm of Twelfth-Century Polyphony (New Haven: Yale University Press, 1954). Examples illustrating the changing style appear in Davison and Apel, op. cit., I, exx. 25-31.$$
37 .
$$

as They are discussed in Reese, Middle Ages, pp.136-

is Several standard works on the history of notation may be consulted for details of these and other paleographical developments, as well as plentiful illustrations: Johannes Wolf, Handbuch der Notationslcunde (2 vols.; Leipzig: Breitkopf und Härtel, 1913-19) ; Willi Apel, The Notation of Polyphonic Music 9001600 (5th ed.) Cambridge: Mediaeval Academy of America, 1961) : Carl Parrish, The Notation of Medieval Music (New York: Norton, 1957). For a special study of Guido and the staff see J. Smits van Waesberghe, "The Musical Notation of Guido of Arezzo," Musica Disciplina, V (1951), 15-53, which includes facsimiles and lists of MSS utilizing the Guidonian system. Other facsimiles: Paléographie Musicale.
}

ern plainchant notation found in the Liber Usualis. Then in the thirteenth century a rapid development began, in which relative lengths or durations came to be ascribed to three of the square notes. This innovation is regarded as the beginning of notation's most prolonged phase, one which was perfected by Vitry in the following century, that of "mensural notation." 35

Principal Manuscripts. There is a rich body of material from this period. All the manuscripts are in legible notation except the well known Winchester Troper, a collection of 164 organums in the eleventh-century neumes, decipherable only in general contour. It is nonetheless of value in the study of techniques in early organum. ${ }^{36}$

From St. Martial the important survivals are B.N. Lat. 1139, 3719, 3549; B.M. Add. MS 36881.

From Notre Dame we have Wolfenbüttel $677 ;^{37}$ Bibl. Laurenziana, Codex Pluteus 29,1; Madrid Bibl. Nac. Hh 167; Wolfenbüttel 1206.38

Three of the numerous secular song collections-chansonniers, as they are called-may be mentioned as representative: Bibl. de l'Arsenal 5198, "Chansonnier de l'Arsenal"; 39 B.N. 844, "Chansonnier du Roy"; ${ }^{40}$ B.N. 25566.41 Other collections are cited in Harvard Dictionary, page 769 .

There are three extremely important

\footnotetext{
${ }^{35}$ Harvard Dictionary, pp.494 f. The major study of notation in this period is Johannes Wolf, Geschichte der Mensuralnotation von 1250-1460 . . . (3 vols.; Leipzig: Breitkopf und Härtel, 1904).

${ }^{33}$ See W. H. Frere, The Winchester Troper (London: Bradshaw Society, 1884), for facsimiles and commentary.

${ }^{27}$ Facsimile in J. H. Baxter, An Old St. Andrews Music Book (London, 1931).

${ }^{28}$ Facsimiles of the Madrid Hh 167 (or 20486) and the Wolfenbüttel 1206 (or 1099) by Luther Dittmer (Brooklyn: Institute of Mediaeval Music, 1957).

Facsimile and transcription by Pierre Aubry (Paris: P. Guenther, 1908).

${ }^{40}$ New edition by J. B. Beck, Les Chansonniers des Troubadours et Trouvères (Philadelphia: University of Pennsylvania Press, 1927).

"Published in E. de Coussemaker, Oeuvres Complètes du Trouvère Adam de la Halle (Paris, 1872).
} 
codices of varied content which date from the thirteenth century: Montpellier, Fac. des Med., H 196; ${ }^{42}$ Bamberg Kg. Bibl. Ed. IV-6; ${ }^{43}$ and Burgos, Spain, "Codex Huelgas."44

The items mentioned appear to predominate among a large number of important sources. ${ }^{45}$

Contemporary Literature on Music. Guido is probably the chief theorist of the time. ${ }^{46}$ Hermannus Contractus ${ }^{47}$ and John Cotton $^{48}$ are authors of valuable treatises. Another work of moment, relating to mensural notation is the "De Musica Mensurabili Positio" of Johannes de Garlandia. ${ }^{49}$

42 Facsimile and transeription in Y. Rokseth, Polyphonies $d u$ xiiie Siecle (Paris: Editions de l'Oiseau Lyre, 1935-39).

Facsimile and transeription in Pierre Aubry, Cent Motets du xiiie Siècle (Paris: Rouart, Lerolle, 1908). See also Friedrich Blum, "Another Look at the Montpellier Organum Treatise," Musica Disciplina, XIII (1959), 15-24.

" Facsimile and transcription in $\mathrm{H}$. Anglès, $E l$ Codex Musical de las Huelgas (Barcelona: Biblioteca de Catalunya, 1931).

4 As guides to other MSS consult the index to Reese, Middle Ages (under "Manuscripts"); Apel, op. cit., pp.201-03; Friedrich Ludwig, Repertorium Organorum Recentioris . . (Halle: Max Niemeyer, $1910)$; W. H. Frere, Biblioteca Musico-Liturgica ... Handlist of the Musical and Latin-Liturgical MSS of the Middle Ages . . . in the Libraries of Great Britain and Ireland (London: B. Quaritch, 1901-32). See also Lincoln B. Spiess, "An Introduction to the Pre-St. Martial Practical Sources of Early Polyphony," Speculum, XXII (1947), 16-17.

For facsimiles the best source is Paléographie Musicale. Others are Apel, Notation; H. M. Bannister, Monumenti Vaticani di Paleografia Musicale Latina (Leipzig: Harrassowitz, 1913) ; E. W. Nicholson, Early Bodleian Music, III (London: Novello; New York: H. W. Gray, 1913) ; Johannes Wolf, Musikalische Schrifttafeln . . . (Bückeburg und Leipzig: F. Kistner \& C. Siegel, 1927).

to Works reprinted in Gerbert, op. cit., II, 2-61 ; Commentaries and partial translations into French in Louis Lambillote, Esthétique, Théorie et Pratique du Chant Grégorien (Paris: A. LeClere, 1855). For two German translations see Reese, Middle Ages, p.127.

4t Definitive text with English translation in Leonard Ellinwood, Musica Hermanni Contracti (Rochester: Eastman School of Music, 1936).

${ }^{48}$ Definitive text of his De Musica, ed. by van Waesberghe (Rome: American Institute of Musicology, 1950). German translation in Utto Kornmüller, "Der Traktat des Johannes Cottonius über Musik," Kirchenmusikalisches Jahrbuch, XIII (1888), I.

4. Text in E. de Coussemaker, Scriptorum de Musica Medii Aevi Nova Seriem ... (Paris: A. Durand, 1864-76). Together, Gerbert, op. cit., and this collection by Coussemaker include all the important medieval treatises on music. Summary of Garlandia in

\section{Fourteenth Through Fifteenth Centuries}

As we near our own time we find more and more details available about musical theory and practice, and more and more extant manuscripts. It is inevitable therefore that this, the final section of the survey, be the most condensed of them all; and that the interested reader will be even more dependent than heretofore upon the suggested references if he wishes to see beneath the surface.

Characteristics of the Music. The fourteenth century has been given the name "Ars Nova," and indeed there was much novelty in the musical picture. For the first time secular music predominated and liturgical music was comparatively neglected; there was new rhythmic freedom; dissonance was treated boldly. Principal composers were Guillaume de Machaut (1300-1377) and Francesco Landini (1325-1397). ${ }^{50}$

A reaction against the new art began in the early fifteenth century, with the so-called Burgundian School, centered around Guillaume Dufay (ca. 14001474). One accomplishment of this school was the final establishment of the third (rather than the fourth or fifth) as the basic interval of harmonic formulation. Sacred music returned to favor.

Succeeding the Burgundians were the Flemish Schools, highlighted by Johannes Ockeghem (1430-1495), Jacob Obrecht (1430-1505), and Josquin des Prez (1450-1521). These men and their contemporaries preferred four-part writing to the three-part texture of the Bur-

Hugo Riemann, Geschichte der Musiktheorie im IX.XIX. Jahrhundert (Leipzig: Max Hesse, 1898), which is also the standard study of the other theorists from the ninth century on. Riemann has been partly translated: Raymond Haggh, History of Music Theory; Books I and II, Polyphonic Theory from the Ninth to the Sixteenth Century [by] Hugo Riemann; translated with a preface, commentary and notes (Lincoln: University of Nebraska Press, 1962).

${ }^{50}$ For a concise view of the fourteenth century, with bibliography, see Harvard Dictionary, pp.56-58. 
gundians, and made numerous other departures of a technical nature. ${ }^{51}$

Notation. Phillipe de Vitry, considered by one authority to be the "father of modern notation," 52 expounded in the treatise "Ars Nova" (from which the century has been named; $c a .1320$ ) a new approach to notation. It became possible to write in duple $(2 / 4,2 / 2$, etc. $)$ as well as in triple $(3 / 4,3 / 2$, etc. ) time, and each note value could be subdivided into two or three of the next smallest value. This system, the mensural notation previously mentioned, remained the norm until $c a$. 1600 with one principal modification: the transition from black to white notes prior to the midfifteenth century. ${ }^{53}$

One aspect of notation not yet mentioned deserves some attention: the method of arranging the various voice parts in the manuscripts. Prior to 1225 , the standard practice was to align simultaneous tones vertically, as in a modern score. Subsequent to that time, as some voice parts came to have many more notes than other parts, this arrangement was found to waste considerable space and writing material; and for it there was substituted the so-called choir book arrangement. In this plan there is no attempt at vertical alignment: each part is written separately, from start to finish, then the next part is written in the same way, etc. The usual arrangement was for two voice parts to occupy one page of the manuscript, with the other one or two voices on the opposite page of the open book. A modern conductor or keyboard player finds this type of distribution exceedingly difficult to read, and doubt has been cast upon the ability of medieval

\footnotetext{
s1 For a thorough study of the period beginning with 1400: Reese, Renaissance, pp.3-287. Brief treatments in Harvard Dictionary, articles on the Burgundian and Flemish Schools.

52 Apel in Harvard Dictionary, p.495. See also note 57 .

${ }^{53}$ Details and facsimiles in Apel, Notation.
}

and renaissance musicians to do so. ${ }^{54}$ In the fifteenth century, choir book arrangement was gradually abandoned in favor of the part-book method, in which each voice is notated on a separate page, so that it is possible to bind together a set of tenor parts or bass parts for a number of compositions; a system corresponding to present practice in orchestral and sometimes on choral arranging.

Score arrangement was revived toward the end of the sixteenth century, and has persisted since then. It should also be noted that bar lines as we know them are not found in the manuscript period.

We find toward the end of this period the introduction of another kind of notation-tablature. Its function was to serve as vehicle for instrumental music. Lute tablatures are of particular interest, for they serve as a guide to finger placement on the instrument, rather than to actual pitches. This system reproduces graphically the fingerboard of the lute, and indicates by signs which strings are to be depressed and where. The technique has certain advantages, and has been revived recently for the notation of guitar and ukulele music. ${ }^{55}$

Principal Manuscripts. As there is a plethora of source material, and the important representatives are given in the Harvard Dictionary, pages 702-03, only four codices will be mentioned here. Those chosen are certainly of very great, if not the greatest, value.

For Landini and other fourteenthcentury Italians: Bibl. Laur. Pal. 87, "Codex Squarcialupi."

(Continued on page 48 )

54 Pros and cons, with an interesting conclusion, in Edward Lowinsky, "On the Use of Scores by Sixteenth-Century Musicians," Journal of the American Musicological Society, I (Spring 1948), 17-22.

s5 For a brief article with illustrations see Harvard Dictionary, pp.728-30. There is a long discussion in Apel, Notation, pp.21-81.

se Modern edition by Johannes Wolf (Lipstadt: Kistner and Siegel, 1955). 